\title{
FOOL THE MARKETS? \\ CREATIVE ACCOUNTING, FISCAL TRANSPARENCY AND SOVEREIGN RISK PREMIA
}

\author{
KERSTIN BERNOTH \\ GUNTRAM B. WOLFF
}

\author{
CESIFO WORKING PAPER NO. 1732 \\ CATEgory 5: Fiscal Policy, MACROECONOMICS AND GROWTH \\ MAY 2006 \\ Presented AT CESifo AREA Conference on \\ Public SECTOR ECONOMICS, APRIL 2006
}

An electronic version of the paper may be downloaded

- from the SSRN website:

- from the RePEc website:

- from the CESifo website:

www.SSRN.com

www.RePEc.org

www.CESifo-group.de 


\title{
FOOL THE MARKETS? \\ CREATIVE ACCOUNTING, FISCAL TRANSPARENCY AND SOVEREIGN RISK PREMIA
}

\begin{abstract}
We investigate the effects of official fiscal data and creative accounting signals on interest rate spreads between bond yields in the European Union. Our model predicts that risk premia contained in government bond spreads should increase in both the official fiscal position and the expected "creative" part of fiscal policy. The relative importance of these two signals depends on the transparency of the country. Greater transparency reduces risk premia. The empirical results confirm the hypotheses. Creative accounting increases the spread. The increase of the risk premium is stronger if financial markets are unsure about the true extent of creative accounting. Fiscal transparency reduces risk premia.
\end{abstract}

JEL Code: G12, E43, E62, H6, F34.

Keywords: risk premia, government bond yields, creative accounting, stock-flow adjustments, gimmickry, transparency.

Kerstin Bernoth

The Netherlands Bank NV

Economic Policy and Research Department 1000 AB Amsterdam

The Netherlands

k.bernoth@dnb.nl
Guntram B. Wolff

German Federal Bank

Economics and Research Department

Wilhelm-Epstein-Str. 14

60431 Frankfurt

Germany

guntram.wolff@bundesbank.de

First draft: January 2006; this draft: May 17, 2006

We thank Mark Hallerberg for many suggestions and for the provision of one fiscal transparency indicator. Jan Marc Berk, Heinz Herrmann, Kenneth Kletzer, Wolfgang Lemke, Harald Uhlig, the research departments of DNB and Deutsche Bundesbank and participants at the University of Münster and the CESifo workshop provided very helpful comments. Remaining errors are ours. The opinions expressed in this paper do not necessarily represent the views of the Deutsche Bundesbank, De Nederlandsche Bank or their staffs. 
"In fact, irrespective of any formal fiscal rules, governments may wish to put the best possible gloss on the accounts presented to the outside world, including the so-called 'bond market vigilantes'." (Koen and van den Noord 2005)

\section{Introduction}

The effect of fiscal variables on bond markets is hotly debated. A topic of particular importance concerns the question, whether and to what extent bond markets price in the possibility of (partial) sovereign default by demanding higher interest rates. If a worsening in the fiscal position of an issuer country increases the default probability, it should also be reflected in an increase of the default risk premium contained in bond yields, measurable by an increase in the interest rate spread towards a low risk benchmark country.

In the previous literature, fiscal determinants of sovereign default risk are quantified by the official fiscal position of a country, usually the official debt and deficit figures. The general empirical finding is that bond yields depend positively on the debt and deficit level (Capeci $(1991,1994)$, Alesina, De Broeck, Prati, and Tabellini (1992), Bernoth, von Hagen, and Schuknecht (2004)). No empirical study so far investigates, whether financial markets are "fooled" by governments if these misreport on their true state of fiscal policy. This is the main purpose of our paper.

Official reported fiscal variables might not give an accurate picture of the true fiscal position of a country for many reasons. Politicians might want to hide deficits if voters dislike them. ${ }^{1}$ Governments might also want to engage in additional spending without having parliamentary approval. Parliamentary control can be reduced by fiscal misreporting. ${ }^{2}$ Moreover, fiscal rules such as constitutional deficit limits and international rules such as the Stability and Growth Pact (SGP) constitute limits on official fiscal data and therefore on fiscal behavior. This might increase the incentive of governments to hide away deficits by reverting to window-dressing or shifting fiscal expenditures off the budget (Milesi-Ferretti 2003). We label these activities 'creative accounting'. Especially the use of creative accounting to 'comply' with the European fiscal rules, namely the excessive deficit procedure (EDP) and the SGP, has recently

\footnotetext{
${ }^{1}$ Alt and Lassen (2006) provide evidence that electoral cycles depend on fiscal transparency. They are less pronounced, the more fiscally transparent a country is. von Hagen and Wolff (2006) show that creative accounting moves with the business cycle.

${ }^{2}$ This is the idea behind the sub-index on fiscal transparency developed in von Hagen (1992).
} 
become an important policy concern in Europe (see e.g. European Commission, 2003).

Numerous studies investigate the effect of fiscal rules on budget outcomes for US states and cities (Bunch (1991), von Hagen (1991), Kiewiet and Szakaly (1996), Bohn and Inman (1996)). The general conclusion from this literature is that binding restraints induce fiscal actors to use other instruments such as creative accounting to dampen the effect of the rule. Relatively few studies investigate the use of "creative" accounting in the EU. ${ }^{3}$ von Hagen and Wolff (2006) are the first to analyze accounting tricks in order to comply with the rules of the SGP. They focus on stock-flow adjustments (SFA), which are defined as the difference between the reported annual change in debt levels and the reported deficits. Positive SFA imply that the debt level increases faster than the deficit data suggest. In particular, they find evidence that SFA was systematically used to reduce the official deficit figures. Koen and van den Noord (2005) collect information on single one-off measures (fiscal gimmickry) and show that the probability to observe such measures increases with the budget deficit. The empirical evidence thus confirms the view that fiscal policy figures are sometimes purposely changed to officially comply with fiscal rules. Significant use of one-off measures can be detected in Europe.

The reaction of financial markets to this creative accounting is an important policy topic. If financial markets do not price in the de facto deterioration of the fiscal position due to creative accounting, while punishing official deficit data, risk premia could be lowered by shifting deficits to creative accounting. The lower interest rate in turn would provide an incentive to governments to beautify their fiscal data. To our knowledge, no study so far analyzes whether financial markets take note of fiscal window-dressing when pricing government bonds. This is the purpose of our study. In particular, we study whether spreads react, besides official fiscal data, to stockflow adjustments or to an alternative measure of creative accounting by Koen and van den Noord (2005).

Furthermore, we investigate, in how far fiscal transparency affects risk spreads. Kopits and Craig (1998) argue that international financial markets are likely to demand lower premia from governments that are forthcoming about their fiscal position and risk. The argument is that markets can be more certain about a

\footnotetext{
${ }^{3}$ Dafflon and Rossi (1999) surveys the accounting tricks used in the run-up to the Euro. They find that numerous countries have used tricks to qualify for EMU membership. Similarly, MilesiFerretti and Moriyama (2004) find that during the period leading up to 1997 governments reduced the public debt ratio by decumulating government assets in order to qualify for EU membership.
} 
fiscally transparent government's ability and willingness to service its obligation. A more transparent budget process in addition helps financial markets to detect creative accounting more easily and to assess the true fiscal position of a country. This might increase the spread since more creative accounting becomes known to the markets. Glennerster and Shin (2006) find that the release of macroeconomic information in the form of publication of the IMF article IV consultation reduces spreads. Their measure does not cover fiscal transparency, however. Gelos and Wei (2005) lend further support to the hypothesis of a risk-reducing role of fiscal transparency by showing that international funds prefer to hold more assets in more transparent countries.

These questions are addressed in the framework of Bernoth et al. (2004). In this paper, the authors derive a simple portfolio model, which shows that the yield spread between a risky and a risk-free country is explained by a default risk premium, a liquidity risk premium, and an uncertainty premium. In their empirical part, they make use of an innovative data set, which consists of spreads between Deutsche Mark (Euro after 1999) and US\$ denominated bond issues of 14 EU governments and Germany or the US government respectively. They show that the interest differentials between sovereign bonds increase with the official figures of the debt and deficit to GDP ratios. In this paper, we modify the basic portfolio model by differentiating between the true fiscal position and the official fiscal position. The default probability assessed by financial markets might differ from the true default probability to the extent that creative accounting exists and is unknown. Transparency by itself reduces uncertainty about the degree of cheating and therefore reduces risk premia.

The next section outlines the model and derives the principle hypotheses. We then present the empirical approach and discuss the data. Section 3 develops the measures of creative accounting and transparency. Section 4 presents and discusses the econometric results while the last section concludes.

\section{Risk premia in government bond markets}

\subsection{A portfolio model of interest rate differentials}

The theoretical model to analyze the impact of creative accounting on bond yield spreads between two countries is an extension of the portfolio model of interest 
differentials described in Bernoth, von Hagen, and Schuknecht (2004). We modify this model by assuming that governments might use creative accounting, which makes the actual fiscal position of a country difficult to observe.

Consider a representative international investor maximizing a utility function that depends positively on expected real wealth, $E_{t}\left[w_{t+1}\right]$ and negatively on its variance, $\operatorname{Var}_{t}\left[w_{t+1}\right]$ :

$$
\operatorname{Max} U\left\{E_{t}\left[w_{t+1}\right], \operatorname{Var}_{t}\left[w_{t+1}\right]\right\}, U_{1}>0, U_{2}<0 .
$$

The investor allocates a fraction $\theta_{t}$ of his real wealth $w_{t}$ to a risky security of country A and a fraction of $1-\theta_{t}$ to a safe security of country B. Both securities and real wealth are priced in the same currency.

For simplicity, we assume that the invested money in A's bonds is lost in case of government default. ${ }^{4}$ Investors incur transaction costs proportional to their investment in bonds which decrease with the liquidity of the bond market. We assume that the bond of country B has benchmark status, i.e., its market is considered to be more liquid than the bond market of country A. Expected wealth then is:

$$
E_{t}\left(w_{t+1}\right)=w_{t}\left(1-\theta_{t}\right)\left(1+r_{t}^{B}\right)-\theta_{t} w_{t} l^{A}+\theta_{t} w_{t}\left(1+r_{t}^{A}\right)\left(1-P_{t}^{e}\right)
$$

where $l_{t}^{A}$ is the expected transaction/liquidity cost on trading a bond of country A and $r_{t}^{i}$ denotes the interest rate on the bond of country $i$, with $i \in A, B{ }^{5} P_{t}^{e}$ denotes the investor's expected default probability, which depends positively on the expected fiscal position of the risky country. Its determinants will be discussed later in this section.

Due to the uncertain investment return of securities of country A, the variance of next period's real wealth of the investor is non-zero and given by:

$$
\operatorname{Var}\left(w_{t+1}\right)=\theta_{t}^{2} w_{t}^{2}\left(1+r_{t}^{A}\right)^{2}\left(\left(1-P_{t}^{e}\right) P_{t}^{e}\right)
$$

Note, that there is no uncertainty regarding the transaction costs in the B market, nor regarding the interest rate on the two different bonds.

Following Dumas (1994), we substitute equation (2) and (3) into the utility function and derive the optimal share invested in the securities of country A, and

\footnotetext{
${ }^{4}$ As shown in Bernoth et al. (2004), this model can easily be extended to the more general case of partial default, i.e. that investors receive a fraction of their gross payment in case of default.

${ }^{5}$ Note that we normalize the transaction cost of the risk free bond market to zero.
} 
get $\widehat{\theta}_{t}$, the optimal share of investment in country A, by utility maximization with respect to $\theta_{t}$ :

$$
\widehat{\theta_{t}}=\frac{\left(1-P_{t}^{e}\right)\left(1+r_{t}^{A}\right)-l_{t}^{A}-\left(1+r_{t}^{B}\right)}{\Phi\left(1+r_{t}^{A}\right)^{2}\left(1-P_{t}^{e}\right) P_{t}^{e}},
$$

where $\Phi=-2 w_{t} U_{2} / U_{1}$ denotes the coefficients of relative risk aversion for the representative investor.

Let $S^{A}$ be the total supply of bonds issued by the government of country A. Equilibrium in the bond market requires that supply is equal to demand and therefore:

$$
S_{t}^{A}=\widehat{\theta}_{t} w_{t}=\frac{w_{t}\left[\left(1-P_{t}^{e}\right)\left(1+r_{t}^{A}\right)-l_{t}^{A}-\left(1+r_{t}^{B}\right)\right]}{\Phi\left(1+r_{t}^{A}\right)^{2}\left(1-P_{t}^{e}\right) P_{t}^{e}} .
$$

which can be solved for the interest rate differential:

$$
\frac{r_{t}^{A}-r_{t}^{B}}{1+r_{t}^{A}}=P_{t}^{e}+\frac{l_{t}^{A}}{1+r_{t}^{A}}+\frac{S^{A}\left(1+r_{t}^{A}\right)^{2}\left(1-P_{t}^{e}\right) P_{t}^{e}}{\left(w_{t} / \Phi\right)\left(1+r_{t}^{A}\right)}
$$

In what follows, by the interest rate spread or differential, we mean the term on the left hand side of the equation.

Equation (6) separates the yield spread between the two bonds into three terms. The first term on the right hand side reflects the default risk premium. The larger the expected default probability, the larger will be the spread. Second, the bond yield differential depends on the liquidity risk premium. The more liquid a bond market, which means low transaction costs $l^{A}$, the smaller will be the liquidity risk premium. The last uncertainty premium depends positively on the variance of the perceived default probability of country $\mathrm{A},\left(1-P_{t}^{e}\right) P_{t}^{e}$. This variance increases with the expected default probability if the expected default probability is smaller 0.5. The last term also increases with the gross nominal return $\left(1+r_{t}^{A}\right)$, and the level of the relative risk aversion of the representative investor $\Phi$. The more the investor cares about the variance of his future wealth $w_{t+1}$ (the larger $U_{2}$ ), the larger will be the interest rate differential between the risky and the risk-free country. Furthermore, the country specific risk premium increases with the total supply of the risky bonds, $S^{A}$.

In the following, we discuss in more detail the determinants of the expected default probability, $P_{t}^{e}$. As pointed out, the spread unambiguously increases with the expected default probability. Transparency and creative accounting enters the model by influencing the expected default probability. We assume that one determinant of the expected default probability is the degree of fiscal transparency. A more 
transparent budget process helps financial markets to detect creative accounting and signals the willingness and ability of governments to serve its obligation. Therefore, we expect that fiscal transparency itself has a negative impact on the expected government's default probability and therefore also on risk premia. This argument finds support in e.g. Kopits and Craig (1998) and Glennerster and Shin (2006).

A further important determinant of the expected default probability, $P_{t}^{e}$, is the expected fiscal position of country $\mathrm{A}, E_{t}\left(B_{t}\right) .{ }^{6}$ The expected default probability increases strictly with the expected fiscal position $\frac{\partial P_{t}^{e}}{\partial E_{t}\left(B_{t}\right)}>0$. For the formation of the expectation of the actual fiscal position, the investor makes use of two information sources. The first is the official publication of the fiscal position, which we call the 'official signal', and the second is a signal coming from news agencies observing the fiscal behavior of governments, which we call the 'news signal'. The official signal is given by:

$$
B_{t}^{O}=B_{t}-c-\eta_{t}
$$

where $c$ is the average amount of creative accounting, $\eta_{t}$ is normally and independently distributed with mean zero and variance $\sigma_{\eta_{t}}^{2}$. The official fiscal position $B_{t}^{O}$ is thus equal to the actual position $B_{t}$, a systematic creative accounting bias $c$ and an error term. We think of the difference between the actual fiscal position and the official one as creative accounting $\left(B_{t}-B_{t}^{O}=C A_{t}=c+\eta_{t}\right)$. From the point of view of the investor, creative accounting is thus an unknown random variable with mean c. The precision of the official signal is given by $\alpha_{t}=\frac{1}{\sigma_{\eta_{t}}^{2}}$.

The news signal the investor receives about the actual fiscal behavior is described by:

$$
B_{t}^{N}=B_{t}+\varepsilon_{t}
$$

where $\varepsilon_{t}$ is again normally and independently distributed with mean zero and variance $\sigma_{\varepsilon_{t}}^{2}$. The precision of this signal is accordingly given by $\beta_{t}=\frac{1}{\sigma_{\varepsilon_{t}}^{2}}$.

Following Bayesian inference, the investor's expectation about the actual fiscal position is:

$$
E\left(B_{t}\right)=\frac{\alpha_{t} \tilde{B_{t}^{O}}+\beta_{t} B_{t}^{N}}{\alpha_{t}+\beta_{t}} .
$$

where $\tilde{B_{t}^{O}}=B_{t}^{O}+c$. Thus, the larger e.g. $\beta_{t}$ relative to $\alpha_{t}$, the more precise and less distorted is the information collected by news agencies about $B_{t}$, and the more

\footnotetext{
${ }^{6}$ Due to the uncertainty concerning the government's use of creative accounting, the expected fiscal position can differ from the actual fiscal position, $B_{t}$.
} 
weight does the investor put on the news signal for forming his believe over $B_{t}$. Rearranging equation (9) leads to:

$$
E\left(B_{t}\right)=\tilde{B_{t}^{O}}+x_{t}\left(B_{t}^{N}-\tilde{B_{t}^{O}}\right),
$$

with $x_{t}=\frac{\beta_{t}}{\alpha_{t}+\beta_{t}}$ denoting the informativeness of the news signal relative to the informativeness of the official signal. We see that the investor's expectation about the actual fiscal position of the government is equal to the officially reported one, $\tilde{B_{t}^{O}}$, plus a correction term due to the use of creative accounting, which is weighted by the relative informativeness of the news signal, $x_{t}$. Note that the difference in the two signals is given by creative accounting and a random term related to the noise in the news signal, i.e., $B_{t}^{N}-\tilde{B_{t}^{O}}=C A_{t}-c+\varepsilon_{t}$. If the informational content of the second signal converges towards zero $(x \rightarrow 0)$, the expectation of the actual fiscal position will be equal to the official announced fiscal position plus average cheating $c$.

Fiscal transparency might have a significant influence on the relative informativeness of the news signal. Fiscal transparency has a disciplinary effect on governments by not only reducing government deficits (see e.g. Alt and Lassen (2006)), but also the use of creative accounting (compare e.g. Koen and van den Noord (2005)). In this case, the precision of the official signal, $\alpha_{t}$, depends positively on fiscal transparency. However, the more transparent the budgetary process of a country is, the easier it is for news agencies to detect creative accounting, which increases also the precision of the news signal, $\beta_{t}$. Therefore, depending on which effect is stronger, fiscal transparency can have a positive or a negative effect on the relative informativeness of the news signal, $x_{t}$, and therefore on the effect of creative accounting on the expected default probability.

\subsection{An empirical model of the determinants of risk premia}

To test the impact of (hidden) fiscal policy on interest rate spreads, we estimate equation (6) as:

$$
\frac{r_{i t}-r_{j t}^{*}}{1+r_{i t}}=\alpha_{1}+\text { fiscal }_{i t} \alpha_{2}+\alpha_{3} C A_{i t}+\alpha_{4} \cdot F T_{i t} \cdot C A_{i t}+\alpha_{5} F T_{i t}+\alpha_{6} z_{i t}+\mu_{i}+\epsilon_{i t}
$$

where $\mu_{i}$ denotes country dummies and $\epsilon_{i t}$ is an error term with usual properties. The dependent variable is the yield spread between a bond issued in EU country $i$ and a benchmark country $j$, both denominated in the same currency. Looking at spreads between bonds issued in the same currency has the advantage that one 
can neglect the issue of exchange rate risk so that data coming from the pre-EMU and post-EMU regimes can be analyzed in one data set. ${ }^{7}$ We regard Germany and the USA as benchmark countries and the joint currency of issuance is the Deutsche Mark (Euro after 1999) or the US\$, respectively.

The government bond data are taken from Capital Data Bondware, which provides a data set with information on the yield, maturity, and underlying currency of government bond issues. ${ }^{8}$ If available, an equivalent benchmark bond is matched to the bond issues, between which the yield spread is then calculated. ${ }^{9}$ We compare government bonds issued by the $15 \mathrm{EU}$ countries, excluding Luxembourg, between 1991 and beginning 2005 that are denominated in Deutsche Mark (DM) before 1998 and subsequently in Euro or alternatively in US\$. Accordingly, the interest differential is measured as the difference in the yield to maturity at the time of issue between the national bond under consideration and an equivalent German government bond in the case of DM/Euro denominated bonds or an equivalent US government bond in the case of a US\$ bond. Figure 2 in the appendix plots the yield spreads of EU government bond issues over time. We see a strong co-movement between the interest differentials of EU countries relative to Germany or the USA and a cyclical pattern.

fiscal includes official fiscal variables influencing the fiscal position of a country and thereby the default probability $P^{e}$. We use the lagged debt to GDP and deficit to GDP ratios as proxies for the fiscal position and its deterioration. ${ }^{10} \mathrm{CA}$ is a creative accounting measure aimed at capturing the news signal, which should affect the expected default probability as it deteriorates the expected state of public finance. The fiscal variables and the creative accounting term are measured as the difference relative to the benchmark country Germany and the USA respectively. ${ }^{11}$

\footnotetext{
${ }^{7}$ Favero, Giavazzi, and Spaventa (1997) discuss the relative performance of this measure with using swap spreads to correct for exchange rate depreciations. They conclude, that both "proxies obviously tend to measure the same phenomenon".

${ }^{8}$ Thanks to Evi Koch for help with Capital Data Bondware.

${ }^{9}$ Capital Data Bondware defines a benchmark bond in the following way. First, it is issued in the same currency, second, it is issued by the government of the country, which owns the issuing currency, third, it has the same coupon payment structure, and, finally, the issuing date is close that of the comparable bond issue it has a comparable time to maturity.

${ }^{10}$ While the debt level is a stock variable controlling for the fiscal position of a country, the deficit measures the deterioration of that position.

${ }^{11}$ More details on $C A$ will be given in the next section. The fiscal data are taken from the AMECO database and are in the definition of the EDP.
} 
We expect both, fiscal and $C A$ to positively affect the spread $\left(\alpha_{2}, \alpha_{3}>0\right)$. FT is a measure of fiscal transparency, which should lower the spread by reducing uncertainty $\left(\alpha_{5}<0\right)$. The effect of $C A$ on the spread might increase or decrease with an increase in transparency, the direction depends on how transparency effects $x_{t}$, that is the informativeness of the news signal relative to the informativeness of the public signal. Increased transparency improves the quality of the news signal, but at the same time reduces the uncertainty about the official signal as more transparent countries probably cheat less. Therefore we expect $\alpha_{4}$ to be larger (smaller) zero, if transparency increases (decreases) $x$.

$\mathrm{z}_{i t}$ is a vector containing several variables affecting the yield spread of the issuing country, i.e. a liquidity variable (liquidity), an indicator of the cyclical stance (cycle) of the economy, a variable measuring the general investors' risk attitude (cor spread), and a maturity variable (maturity).

The liquidity variable serves to estimate the liquidity premium. We cannot follow one of the conventional approaches to use bid-ask spreads, which reflect trading costs in trading securities (Flemming 2003) as a measure for liquidity, since this information is not reported for primary issues. Gravelle (1999) shows that the correlation between bid-ask spreads and the total supply of debt is significantly negative. This suggests that the total volume of supply of a security has a positive effect on its liquidity, an argument put forward also by Gómez-Puig (2006). Following this reasoning, we assume as Bernoth, von Hagen, and Schuknecht (2004) that liquidity depends on market size and, additionally, that all debt issued by a government in a given currency is homogeneous up to maturity. Thus, the liquidity premium is assumed to be proportional to the ratio of the debt issued by a government in $\mathrm{DM} /$ Euro or US\$ to the total debt of EU countries issued in DM/Euro or US\$. ${ }^{12}$ Measuring liquidity by the market share of foreign denominated debt assures additionally a low correlation between our liquidity variable and the debt/GDP variable.

The inclusion of an indicator of the cyclical stance (cycle) is motivated by the idea that default risk depends on the overall economic situation of a country. In an economic slow-down, government revenues decrease, while expenditures increase, and the probability of default may rise. Our indicator takes the value 1 , when the nominal GDP of a country is more than half a standard deviation above its trend

\footnotetext{
${ }^{12} \mathrm{We}$ also used the issue size as an alternative proxy for liquidity, but since this variable shows insignificant coefficients, we exclude it from reported regression analysis. The other regression coefficients remained unaffected.
} 
(boom), (-1) when it is more than half a standard deviation below its trend (recession), and 0 otherwise. The cycle variable included in the regression is calculated as the difference of this indicator between the issuer and the benchmark country. ${ }^{13}$

As suggested by our model as well by several empirical studies,${ }^{14}$ one important determinant of yield spread between countries is the general investors' risk aversion towards credit risk. Since investors' risk aversion is not directly observable, we use, similar to Codogno, Favero, and Missale (2003) Favero and Giavazzi (2004), and Bernoth, von Hagen, and Schuknecht (2004)), the yield spread between low grade US corporate bonds (BBB) and benchmark US government bonds as an empirical proxy. A rise in this spread indicates an increase in the investors' risk aversion, and vice versa.

We expect, that an investor demands a compensation for investing in long-term bonds instead of buying short-term bonds as the default risk increases with time to maturity. Given that our data set contains bond issues with different times to maturity, this motivates the inclusion of a maturity variable to our regression equation, which measures the time to maturity of the bonds at the time of issue.

Since we have data before and after the introduction of the Euro, we have to augment the above equation. More precisely, we estimate the following equation:

$$
\begin{aligned}
\frac{r_{i t}-r_{j t}}{1+r_{i t}} & =f_{i s c a l}\left(\mu_{1}+\mu_{2} E M U\right)+C A_{i t}\left(\xi_{1}+\xi_{2} F T_{i t}+\xi_{3} E M U\right)+\beta_{1} F T_{i t}+ \\
& +z_{i t}\left(\alpha_{1}+\alpha_{2} E M U\right)+\alpha_{3} E M U+\mu_{i}+\epsilon_{i t}
\end{aligned}
$$

where $\mu_{i}$ denotes country dummies and $\epsilon_{i t}$ is an error term with usual properties. To estimate the effects of EMU on yield spreads, we use the EMU dummy which takes the value of one for all EMU member countries as of 1998 and for Greece as of 2000 and zero otherwise. ${ }^{15}$ A significant coefficient on this dummy points to a

\footnotetext{
${ }^{13}$ Thus, cycle is zero, if both countries are in the same cyclical position; it is $(-2)$ and (2), if one is in a strong boom and the other in a strong recession, and $(-1)$ and 1 in the case of less severe differences in the cyclical stance.

${ }^{14}$ E.g. Dungey, Martin, and Pagan (2000) provide strong evidence of a common international factor in many yield differentials. Codogno, Favero, and Missale (2003) and Pagano and Thadden (2004) also note considerable co-movement of yield spreads, probably driven by international risk factors. Bernoth, von Hagen, and Schuknecht (2004)) confirm as well that interest differentials between EU countries are significantly affected by international risk factors and that the USA enjoy a 'safe haven' status.

${ }^{15}$ We included the year 1998 in the EMU dummy since the decision, which countries would participate was made public in May of 1998 and was ex hypothesi correctly expected.
} 
general effect of EMU on yield spreads of all member countries. Furthermore, we interact the $E M U$ dummy with the fiscal variables, and the liquidity variable to see whether EMU has changed the effect of the fiscal variables, creative accounting, and market liquidity on interest rates.

Before estimating equation (12) we tested, whether we can pool DM/Euro and US $\$$ bonds into one data set. That means that we test, whether the effects of the independent variables on the spreads are the same for both currency groups. We find that, except for the effects of corporate-government spreads, pooling is permissable. Thus, we estimate for the variable corspread for both currency groups separate slope coefficients. To do that, we add a variable to our regression that interacts the variable corspread with a dummy that takes the value one, if a bond is issued in US\$.

Finally, we include country dummies to control for unobserved country characteristics. This is especially relevant in the current context, as some countries have a reputation of frequent fiscal misreporting. The coefficients of creative accounting including countries dummies thus really captures the change of the country's risk premium due to the new signal. It does not capture the bad reputation of that country.

Detailed summary statistics of all mentioned variables are given in Table 3 in the appendix.

\section{Creative accounting and fiscal transparency}

\subsection{Creative accounting}

Measuring creative accounting is - by definition - difficult as it is an unpublished and hidden fiscal activity. Therefore, in our empirical exercise, we have to resort to approximate measures for the true extent of creative accounting. We employ two different measures, both measures only approximate the true extent of creative accounting. Both measures come from generally available information sources and therefore represent "news" signals to the financial markets. The first one is a noisy measure of creative accounting, namely stock-flow adjustments in percent of GDP. Following von Hagen and Wolff (2006), they are calculated from equation (13) as the difference between the change in the debt level $B$ and the deficit $D$.

$$
B_{t}-B_{t-1}-D_{t}=S F A_{t}
$$


The advantage of this measure is that it captures all events that have an effect on the debt level without being recorded in the budget. This advantage is also the measure's main weakness, as some operations might not reflect the attempt to improve the books but result from purely technical problems that do not necessarily have an effect on the default probability of a country. ${ }^{16}$ Overall, these "noisy" parts of the measure are probably random and should tend to cancel out over time (European Comission, DG for Economic and Financial Affairs 2003, p.79). von Hagen and Wolff (2006), however, show that stock-flow adjustments observed in Europe are on average positive over long periods of time. They also show that SFA is actively used by governments as a creative accounting tool. Buti, Martins, and Turrini (2006) extend and confirm these results. This creative accounting part contained in SFA should have a significant effect on interest rates, if it is recognized by financial markets as increasing the risk of default.

As a second measure of creative accounting, we employ the data presented in Koen and van den Noord (2005), who collect individual one-off measures to window dress the budget. The measure, called 'fiscal gimmickry', is a non-exhaustive inventory of events that have become public knowledge through media coverage. It is a more "fine tuned" measure of creative government activities than SFA. However, it is very likely, that many of such operations are unnoticed by news agencies and are therefore not collected in this database. Thus, while SFA probably captures a broader range of creative accounting but is measured with noise because of "noncreative" parts of SFA, 'fiscal gimmickry' is a 'pure' measure of creative accounting but captures only the window-dressing activities that became public knowledge and have been collected in the data base.

Figure 1 shows the relationship between stock-flow adjustments and one-off measures as collected by Koen and van den Noord (2005). We can clearly see a positive relationship, suggesting that the two measures probably both give similar and valuable information of creative accounting.

Summary statistic of our two creative accounting variables are shown in Table 3 in the appendix.

\footnotetext{
${ }^{16}$ For example, positive SFA resulting from exchange rate re-valuation of foreign denominated debt are connected with a change in the ability of governments to service the debt, while positive SFA resulting from building up assets leaves the default probability unaffected.
} 


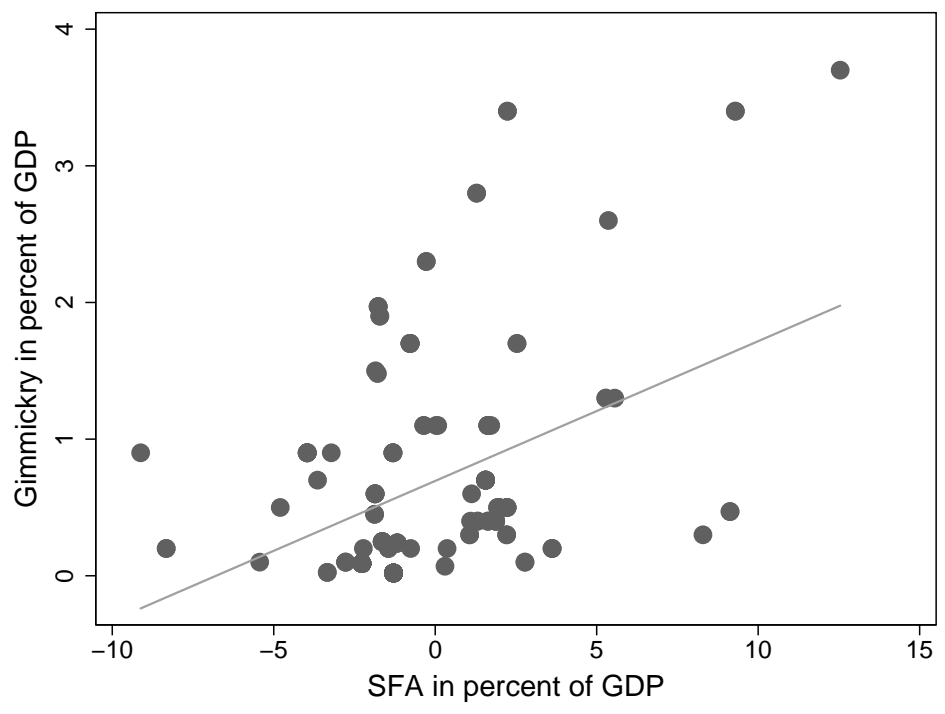

Figure 1: The relation between stock-flow adjustments and fiscal gimmickry taken from Koen and Noord (2005) in percent of GDP, when gimmickry is observed.

\subsection{Fiscal transparency}

Fiscal transparency is an important concept, which is, however, difficult to measure. The IMF's concept of fiscal transparency is defined in their manual on fiscal transparency. ${ }^{17}$ This definition, which emphasizes being open to the public about the structure and functions of government, fiscal policy intentions, public sector accounts, and fiscal projections is based on Kopits and Craig (1998). ${ }^{18}$

In our paper, we think of transparency in a more narrow sense as influencing the relative information content of the official deficit signal and further creative accounting news. This narrower concept is also used to define transparency by Poterba and von Hagen (1999, pp. 3-4): "A transparent budget process is one that provides clear information on all aspects of government fiscal policy. Budgets that

\footnotetext{
${ }^{17} \mathrm{http} / / /$ www.imf.org/external/np/fad/trans/manual/intro.htm

${ }^{18}$ The IMF code includes four general principles of fiscal transparency. The first general principle, Clarity of Roles and Responsibilities, is concerned with specifying the structure and functions of government, responsibilities within government, and relations between government and the rest of the economy. The second general principle, Public Availability of Information, emphasizes the importance of publishing comprehensive fiscal information at clearly specified times. The third general principle, Open Budget Preparation, Execution, and Reporting, covers the type of information that is made available about the budget process. The fourth general principle, Assurances of Integrity, deals with the quality of fiscal data and the need for independent scrutiny of fiscal information.
} 
include numerous special accounts and that fail to consolidate all fiscal activity into a single 'bottom line' measure are not transparent. Budgets that are easily available to the public and to participants in the policymaking process, and that do present consolidated information, are transparent."

We capture the concept of informational transparency with two measures. One is a newly developed index of auditing, called Audit. This index is calculated on the basis of the answers collected by an OECD and World bank survey conducted in 2003. A detailed description of the derivation of this index is given in the Appendix. Audit measures whether governments are financially audited externally, how independent the auditing can be performed and how well the obtained information is disseminated.

The other index used is based on a part of the indicator developed in the seminal paper by von Hagen (1992), extended in Hallerberg, Strauch, and von Hagen (2001) and updated in Hallerberg, Strauch, and von Hagen (2005). We call this indicator Transparency, it is a measure of informativeness and transparency of the budget draft and includes an assessment of transparency given by government officials, the degree to which special funds are included in the budget draft, the information whether the budget consists of one document, whether it is linked to national accounts and finally whether government loans are included.

In comparison to Audit, Transparency is up-dated twice over the investigated time period, and therefore also takes the development of 'budgetary transparency' over time into account. Hallerberg, Strauch, and von Hagen (2005) show that there has been a general increase in the level of transparency in Europe over the covered time period. Figure 3 in the Appendix compares the two measures of fiscal transparency for the year 2003. As can be seen, both are positively correlated. Table 3 in the appendix describes the descriptive statistics of these two transparency variables.

For both measures of fiscal transparency, we expect a negative impact on default risk premia asked by financial markets. Thus, the better governments are audited and the better the public information on the budget, the lower the spread. The hypothesis underlying this prediction is that financial markets know about transparency and will penalize in-transparent institutions, as they have less information on the true state of public finance. Furthermore, more transparency might increase the bargaining power of lenders in case of debt restructuring and thereby lower the risk of losing out completely on a credit.

Figures 4 and 5 in the appendix suggest that there exists a negative relation- 
ship between fiscal transparency and creative accounting. Thus, a country with a highly transparent budgetary process uses less fiscal window-dressing activities than a less transparent country. A logit regression between a binary variable, that takes the value of 1 if a country used fiscal gimmickry and zero otherwise, and the Transparency index confirms this result. However, the causality between these two variables is unclear. It might be that lower scores on fiscal transparency raise the odds of gimmickry, because the probability of detection is small. Alternatively, countries that have less incentive/need to hide parts of their fiscal position might introduce a highly transparent budgetary process to signal their trustworthiness to financial markets.

Figures 6 and 7 in the appendix plot the relation between the variance of publicly known creative accounting and the level of fiscal transparency. These graphs confirm the prediction, that transparency and the uncertainty of (measured) creative accounting are negatively correlated.

A simple correlation analysis between spreads and the two measures of creative accounting provides first evidence, that there exist a significant positive relationship between interest rates and hidden fiscal policy. For stock-flow adjustments this positive correlation is significant at a 5 percent level, while for gimmickry it is significant at a 1 percent level. The next section provides more econometric evidence on these effects.

\section{Results}

\subsection{Baseline results}

Table 1 presents our estimation results. All regressions are estimated with country fixed effects to control for unobserved country characteristics. ${ }^{19}$ Our results confirm the previous results of Bernoth, von Hagen, and Schuknecht (2004). Deficits significantly increase risk premia. ${ }^{20}$ According to column A, a deficit differential of five percent relative to the benchmark country explains a yield differential of around 20

\footnotetext{
${ }^{19}$ We also estimated regression (12) without country fixed effects to exploit as well the crosscountry dimension of our data. The estimation results are qualitatively similar and are available from the authors on request.

${ }^{20}$ Only in two regressions deficits become insignificant since their effect can not be separated from the effect of fiscal transparency.
} 
basis points. However, the significant negative coefficient on deficit $* E M U$ indicates that with EMU the effect of deficits on risk premia is significantly reduced. In fact, an $F$-test on the sum of the coefficients for deficit and deficit *EMU does not allow to reject the null hypothesis of no influence of the deficit on the spread with an EMU membership.

Before 1999 and for non-EMU countries thereafter, we find a significant and positive effect of fiscal gimmickry on government bond yields. The coefficient for stock-flow adjustments shows as well the expected positive sign, but is significant at the 10 percent significance level in only 3 out of 5 regressions. A reasonable explanation for the weak significance of stock-flow adjustments is that this measure of creative accounting is, as described earlier, a noisy measure for creative accounting. All in all, we can summarize that financial markets recognize window-dressing of governments and are not completely fooled. Financial markets thus demand higher interest rates if a government uses creative accounting.

Interestingly, the effects of the two different CA measures and the effects of the deficit, are quantitatively substantially different. While an increase in stock-flow adjustments by one percent of GDP increases the spreads by less than one basis point (and is not always significant), the effect of an equivalent increase in gimmickry amounts to up to 20 basis points. Increasing the deficit by one percentage point will lead to an increase of the spread by roughly three basis points. The difference in coefficient size needs to be explained. In fact, if all three variables were perfect measures of the factual deterioration of the fiscal stance of the economy, they should all equally affect the probability of default. The estimated coefficients should be the same as they measure the increase in the spread due to the equally increased default probability.

The difference in coefficient sizes can result from two sources. First, sfa is a very rough measure of creative accounting. It is well known, that if a variable is measured with error, the coefficient is biased towards zero (the so called attenuation bias). If sfa measures the actual deterioration of the fiscal position with more noise than the deficit, and if the noise is well-behaved, the difference in size of the coefficient vis-a-vis the deficit coefficient might actually result from this attenuation bias. The estimated coefficient for sfa is thus a lower bound for the true impact of creative accounting on spreads.

However, the argument that the attenuation bias also explains the discrepancy between the coefficients of sfa and gimmickry, does not seem to be plausible. sfa must 
be extremely noisy to actually explain the huge difference in these two coefficients. Therefore, we believe that the large size of the fiscal gimmickry coefficient must result from something else. The data on which "gimmickry" is based come from creative accounting events that become public knowledge in the media. Apparently, financial markets react more strongly to these events than to more hidden creative accounting, which we capture with sfa. Figure 1 indicates why the reaction to sfa should be smaller than to gimmickry. As can be seen, gimmickry increases less than one-to-one compared to sfa. This implies that the coefficient of sfa should be lower than the one of gimmickry. Probably, financial markets assume that the gimmickry becoming public knowledge is just the tip of the iceberg. In this interpretation, gimmickry data represent a huge signal of additional hidden fiscal profligacy, which is penalized accordingly by financial markets.

After acceptance to EMU, the effect of cheating on the risk premium is significantly reduced, as indicated by the negative and significant coefficients on $s f a * E M U$ and gimmickry $* E M U$. Comparable to the weakening of the deficit effect, an $F$-test cannot reject the null hypothesis of no significant relationship between stock-flow adjustments and interest rate spreads after the start of EMU. Once inside the Euro, financial markets thus basically become indifferent to the cheating of individual EMU members. ${ }^{21}$

We do not find a significant relationship between the lagged debt level and the yield spread. This suggests that financial markets mostly react to the deterioration of the fiscal position and not to its overall level. A reasonable explanation is that the influence of the relatively time-invariant debt level on interest spreads is almost entirely absorbed in the estimated country-fixed effects.

Before EMU and for non-EMU countries after 1999, we find a significant liquidity effect on interest rate spreads in most regressions. According to column A, an increase of the relative debt market size by five percent causes a reduction of the yield spread by around four basis points. As indicated by the significant coefficients on Liquidity * EMU, EMU-membership reduces the liquidity premium contained in government bond yields. A F-test does not reject the hypothesis that liquidity premia even vanish with EMU. An explanation is that this results from the improved integration of markets, which lowers transaction costs. This result is in line with Pagano and Thadden (2004), who also conclude that liquidity premia play a smaller

\footnotetext{
${ }^{21}$ Anecdotal evidence from significant deficit and debt data revisions in some countries in recent years confirms this finding as risk premia moved very little in these cases.
} 
role in explaining yield differentials after EMU membership.

As indicated by the significant coefficient of corspread $* U S$, we find for yield differentials relative to the USA a significant effect of the general investors' risk aversion. The more risk averse investors are towards credit risk, which is indicated by a large spread between low-graded US corporate bonds and US government bonds, the wider is the interest differential between an EU country and the USA. For bond yield spreads relative to Germany, we do not find this effect. This shows that, contrarily to Germany, the USA enjoy a 'safe haven' status and that international factors have a significant effect on government bond yield spreads, which is in line with the results of e.g. Codogno et al. (2003), Gomez-Puig (2005) and Bernoth et al (2004). The other control variables have the expected signs and will not be discussed further at this place.

Columns B and D extend the regression by two alternative measures for fiscal transparency. In all regression with gimmickry, we find a significant reduction of the spread, the more transparent the budgetary process of a government is. An increase of the audit as well the transparency measure taken from Hallerberg, Strauch, and von Hagen (2005) by one standard deviation causes an decrease of the yield differential by roughly 6 basis points. ${ }^{22}$ For both transparency measures, we find the statistical significance of the coefficients on creative accounting to remain unaffected. This shows, that the significant results of creative accounting do not result from an omitted variable bias because of missing transparency proxies. Overall, our evidence suggest that fiscally more transparent countries have to pay lower risk premia. This evidence confirms the prediction by Kopits and Craig (1998) that financial markets can be more certain about a fiscally transparent government's ability and willingness to service its obligation and therefore demand lower risk premia.

In Columns $\mathrm{C}$ and $\mathrm{E}$, we presents the estimation results for gimmickry and sfa interacted with our two measures for fiscal transparency. We find a strong and significant negative effect for gimmickry interacted with Audit and Transparency. This indicates that financial markets are less worried about gimmickry of a transparent country. This probably means that gimmickry is not perceived as a very bad signal of the tip of the iceberg if the budgetary process of a government is relatively transparent. In terms of the model interpretation, improved auditing respectively transparency has a stronger effect on the reliability of the official signal as compared

\footnotetext{
${ }^{22}$ Note, that we cannot control for country dummies in this regression, since Audit is time invariant.
} 
to the precision of the news signal. Fiscal transparency thus probably reduces the odds of creative accounting strongly.

Our results provide evidence, that financial markets care about creative accounting. Creative accounting results in higher risk premia. Since creative accounting measured by gimmickry is significant in all specifications with included country dummies, financial markets appear to value the de facto deterioration of the intertemporal budget situation. This indicates, that financial markets do not only take creative accounting exclusively as a signal of the country's general characteristics. They rather evaluate the actual deterioration of the fiscal position of the country resulting from creative accounting.

The different size of the coefficient for gimmickry and sfa provides some evidence, that public knowledge of this creative accounting plays a crucial role for financial markets. Recall that the gimmickry data are based on cases of fiscal cheating that made it in the news. These bad "cheating-news" strongly degrade the perception of risk of a country. Financial markets' risk assessment is, however, less affected by gimmickry, the more transparent a country is. 
Table 1: Creative accounting, fiscal transpareny and risk premia in government bond markets

\begin{tabular}{|c|c|c|c|c|c|c|c|c|c|c|c|}
\hline & $\overline{\mathrm{A}}$ & $\mathrm{B}$ & $\bar{C}$ & $\overline{\mathrm{D}}$ & $\mathrm{E}$ & & $\bar{A}$ & $\bar{B}$ & $\bar{C}$ & $\overline{\mathrm{D}}$ & $\bar{E}$ \\
\hline \multirow[t]{2}{*}{ deficit } & 3.98 & 3.66 & 3.69 & 4.18 & 4.14 & deficit & 2.58 & 1.09 & 0.64 & 2.01 & 2.08 \\
\hline & 3.15 & 2.04 & 2.06 & 3.41 & 3.72 & & 3.41 & 1.11 & 0.73 & 2.59 & 2.9 \\
\hline \multirow[t]{2}{*}{ sfa } & 0.50 & 0.48 & 0.96 & 0.47 & 0.56 & gimmickry & 17.20 & 20.50 & 43.98 & 22.53 & 20.51 \\
\hline & 1.74 & 1.65 & 0.84 & 1.67 & 1.43 & & 3.96 & 4.39 & 6.05 & 4.94 & 5.08 \\
\hline \multirow[t]{2}{*}{$\operatorname{debt}(-1)$} & 0.18 & 0.12 & 0.11 & 0.07 & 0.07 & $\operatorname{debt}(-1)$ & -0.06 & 0.02 & 0.07 & -0.05 & -0.04 \\
\hline & 1.14 & 0.67 & 0.58 & 0.79 & 0.9 & & -0.46 & 0.15 & 0.52 & -0.66 & -0.55 \\
\hline \multirow[t]{2}{*}{ liquidity } & -0.88 & -0.92 & -0.99 & -0.59 & -0.60 & liquidity & -0.49 & -0.49 & -0.35 & -0.24 & -0.19 \\
\hline & -2.32 & -2.44 & -2.26 & -1.57 & -1.61 & & -1.85 & -1.8 & -1.42 & -0.99 & -0.86 \\
\hline \multirow[t]{2}{*}{ corspread } & 0.05 & 0.05 & 0.04 & 0.04 & 0.05 & corspread & 0.00 & 0.05 & 0.04 & 0.02 & 0.03 \\
\hline & 0.96 & 0.92 & 0.84 & 1.15 & 1.17 & & -0.02 & 0.89 & 0.79 & 0.6 & 0.74 \\
\hline \multirow[t]{2}{*}{ US } & -40.40 & -40.63 & -41.70 & -47.61 & -47.15 & US & -54.42 & -45.75 & -43.45 & -56.08 & -52.12 \\
\hline & -3.68 & -3.5 & -3.42 & -5.33 & -5.28 & & -5.27 & -4.31 & -4.07 & -6.32 & -5.89 \\
\hline \multirow[t]{2}{*}{ corspread*US } & 0.40 & 0.40 & 0.41 & 0.40 & 0.40 & corspread*US $^{*}$ & 0.47 & 0.42 & 0.41 & 0.44 & 0.42 \\
\hline & 6.5 & 6.29 & 6.07 & 8.26 & 8.26 & & 8.16 & 7.28 & 7.11 & 8.96 & 8.65 \\
\hline \multirow[t]{2}{*}{ cycle } & -3.30 & -3.40 & -3.54 & -3.76 & -3.85 & cycle & -1.00 & -0.75 & -0.82 & -1.13 & -1.04 \\
\hline & -2.67 & -2.76 & -2.84 & -3.09 & -3.28 & & -0.78 & -0.57 & -0.65 & -0.77 & -0.71 \\
\hline \multirow{2}{*}{ maturity } & 0.83 & 0.80 & 0.80 & 0.79 & 0.80 & maturity & 1.18 & 1.18 & 1.20 & 1.07 & 1.07 \\
\hline & 2.78 & 2.61 & 2.6 & 2.71 & 2.73 & & 3.65 & 3.61 & 3.74 & 3.82 & 3.88 \\
\hline \multirow[t]{2}{*}{ EMU } & -13.28 & -12.80 & -13.02 & -9.45 & -9.17 & EMU & 2.34 & -0.07 & -0.81 & 3.12 & 2.40 \\
\hline & -2.18 & -2.13 & -2.14 & -1.62 & -1.68 & & 0.5 & -0.02 & -0.18 & 0.71 & 0.55 \\
\hline \multirow[t]{2}{*}{ deficit*EMU } & -4.49 & -4.09 & -4.20 & -3.81 & -3.90 & deficit*EMU & -1.89 & -0.14 & 0.49 & -1.28 & -1.28 \\
\hline & -3.05 & -2.09 & -2.07 & -2.82 & -2.75 & & -2.07 & -0.11 & 0.45 & -1.45 & -1.5 \\
\hline \multirow[t]{2}{*}{ sfa*EMU } & -1.35 & -1.36 & -1.34 & -0.68 & -0.80 & gimmickry*EMU & -24.28 & -27.61 & -27.70 & -26.69 & -26.14 \\
\hline & -2.43 & -2.46 & -2.43 & -1.35 & -1.29 & & -5.66 & -5.98 & -6.92 & -5.91 & -6.48 \\
\hline \multirow{2}{*}{$\operatorname{debt}(-1) * \mathrm{EMU}$} & -0.13 & -0.18 & -0.17 & -0.11 & -0.13 & $\operatorname{debt}(-1) * \mathrm{EMU}$ & 0.16 & 0.16 & 0.26 & 0.14 & 0.09 \\
\hline & -0.86 & -1.11 & -1.1 & -0.98 & -1.08 & & 1.36 & 1.41 & 2.07 & 1.43 & 0.87 \\
\hline \multirow[t]{2}{*}{ liquidity*EMU } & 1.03 & 1.14 & 1.17 & 0.66 & 0.66 & liquidity*EMU & 0.35 & 0.55 & 0.50 & 0.03 & 0.12 \\
\hline & 2.29 & 2.7 & 2.65 & 1.63 & 1.67 & & 1.16 & 1.76 & 1.69 & 0.09 & 0.41 \\
\hline \multirow[t]{2}{*}{ transparency } & & -14.89 & -17.38 & & & transparency & & -41.08 & -29.85 & & \\
\hline & & -0.73 & -0.91 & & & & & -2.52 & -1.73 & & \\
\hline \multirow[t]{2}{*}{ transparency*SFA } & & & -0.72 & & & transparency* gimmickry & & & -37.78 & & \\
\hline & & & -0.46 & & & & & & -2.75 & & \\
\hline \multirow[t]{2}{*}{ audit } & & & & -37.95 & -35.53 & audit & & & & -41.36 & -19.54 \\
\hline & & & & -3.26 & -2.9 & & & & & -3.61 & -1.29 \\
\hline \multirow[t]{2}{*}{ audit*SFA } & & & & & -1.13 & audit*gimmickry & & & & & -16.81 \\
\hline & & & & & -0.45 & & & & & & -2.33 \\
\hline \multirow[t]{2}{*}{ cons } & 12.19 & 25.78 & 29.42 & 18.45 & 17.10 & cons & -22.30 & 3.98 & -4.87 & 13.05 & 8.64 \\
\hline & 1.37 & 1.17 & 1.42 & 2.33 & 2.21 & & -1.47 & 0.2 & -0.24 & 1.73 & 1.11 \\
\hline country dummies & yes & yes & yes & no & no & & yes & yes & yes & no & no \\
\hline $\mathrm{N}$ & 235 & 234 & 234 & 234 & 234 & $\mathrm{~N}$ & 208 & 208 & 208 & 207 & 207 \\
\hline $\mathrm{r} 2$ & 0.65 & 0.66 & 0.66 & 0.60 & 0.60 & $\mathrm{r} 2$ & 0.74 & 0.75 & 0.76 & 0.71 & 0.71 \\
\hline
\end{tabular}

Notes: t-values below the coefficient. 


\subsection{Robustness checks}

Table 2 shows IV regressions to address the potential attenuation bias resulting from the imprecise measurement of creative accounting through stock-flow adjustments. If the coefficient is downward biased because of the attenuation bias, we expect the coefficients on sfa to be larger in the instrumental variables regressions. We instrument sfa with fiscal gimmickry and find the expected result. The coefficient for sfa is now larger and closer to the one on fiscal gimmickry.

Table 2: Instrumental variables regressions for stock-flow adjustments

\begin{tabular}{|c|c|c|c|c|}
\hline \multirow[t]{2}{*}{$\overline{\mathrm{sfa}}$} & 11.97 & $\overline{7.91}$ & 1.40 & 1.83 \\
\hline & 2.21 & 0.43 & 1.17 & 1.67 \\
\hline \multirow[t]{2}{*}{ sfa*EMU } & -10.54 & -13.99 & 4.92 & -0.31 \\
\hline & -1.91 & -0.97 & 1.52 & -0.07 \\
\hline \multirow[t]{2}{*}{ deficit } & 5.48 & 5.83 & 4.41 & 4.50 \\
\hline & 1.84 & 0.73 & 2.83 & 2.65 \\
\hline \multirow[t]{2}{*}{$\operatorname{debt}(-1)$} & 0.61 & 1.59 & 0.08 & 0.21 \\
\hline & 1.53 & 0.37 & 0.72 & 0.82 \\
\hline \multirow[t]{2}{*}{ liquidity3 } & 0.68 & 0.38 & -0.53 & -0.88 \\
\hline & 0.42 & 0.17 & -1.06 & -1.73 \\
\hline \multirow[t]{2}{*}{ corspread } & 0.02 & 0.04 & 0.08 & 0.01 \\
\hline & 0.17 & 0.1 & 1.13 & 0.21 \\
\hline \multirow[t]{2}{*}{ US } & -27.88 & -8.47 & -23.94 & -38.94 \\
\hline & -0.79 & -0.04 & -1.58 & -2.85 \\
\hline \multirow[t]{2}{*}{ corspread*US } & 0.34 & 0.34 & 0.27 & 0.40 \\
\hline & 2 & 0.39 & 2.93 & 4.84 \\
\hline \multirow[t]{2}{*}{ cycle } & -21.06 & -15.20 & -0.62 & -3.17 \\
\hline & -1.8 & -0.56 & -0.19 & -1.4 \\
\hline \multirow[t]{2}{*}{ maturity } & 1.30 & 2.33 & 0.84 & 1.21 \\
\hline & 1.67 & 1.29 & 2.05 & 2.93 \\
\hline \multirow[t]{2}{*}{ EMU } & -4.12 & 12.88 & -12.27 & -8.10 \\
\hline & -0.23 & 0.36 & -1.37 & -1.06 \\
\hline \multirow[t]{2}{*}{ deficit*EMU } & -3.79 & -16.36 & 3.86 & -2.53 \\
\hline & -0.99 & -1.61 & 1.13 & -0.46 \\
\hline \multirow[t]{2}{*}{$\operatorname{debt}(-1)$ EMU } & -0.60 & -0.17 & -0.05 & -0.06 \\
\hline & -1.26 & -0.31 & -0.27 & -0.26 \\
\hline \multirow[t]{2}{*}{ liquidity $3 * E M U$} & -0.36 & -0.07 & 0.21 & 0.62 \\
\hline & -0.23 & -0.02 & 0.39 & 1.09 \\
\hline \multirow[t]{2}{*}{ cons } & 1.23 & -36.89 & 9.74 & 33.02 \\
\hline & 0.04 & -0.1 & 0.83 & 1.12 \\
\hline country dummies & no & yes & no & yes \\
\hline instruments & $\begin{array}{c}\text { gimmickry } \\
\text { gimmickry*EMU }\end{array}$ & & $\begin{array}{c}\text { transparencyMH } \\
\text { FisGovStructure } \\
\text { elect2 } \\
\text { vetoman }\end{array}$ & \\
\hline $\mathrm{N}$ & 208 & 208 & 225 & 225 \\
\hline
\end{tabular}

Notes: t-values below the coefficient.

Our estimates might suffer from endogeneity if governments use creative accounting to "fool" the financial markets. In this case, the estimated coefficients will be 
biased, as they are driven by reverse causality. In this view, governments engage in creative accounting when the spreads are larger in order to reduce the risk premium and the connected interest payments. While it is very likely that other factors, especially fiscal rules and electoral motives, determine the incentives of governments more than the relatively small spreads in the EU, we want to make sure that our coefficients are not driven by a possible reverse causality problem. Therefore, we perform a second sets of instrumental variable regressions in Table 2.

In the second set of IV regressions, we instrument sfa with political economy variables. It is reasonable to assume, that variables measuring political and especially institutional features of an economy are exogenous to the interest rate spread. They are, however, very likely to be connected to the amount of creative accounting. In particular, we employ the transparency measure Transparency, a dummy variable taking the value 1 in election years, a variable measuring the quality of the budget process and a variable for the raw ideological distance (vetoman) within a government. ${ }^{23}$ Following Hallerberg (2004), we expect better budgeting institutions to contribute to lower use of sfa, while governments might be particularly tempted to use sfa in election years. Finally, we expect that the larger the ideological distance in a government, the more difficult it will be to agree on hiding parts of the budget from the books. The first stage regressions confirm these predictions. As Table 2 shows, the instrumented sfa has the expected effect on the spread and is statistically significant when controlling for country dummies. We are therefore confident, that our measured coefficients on creative accounting are not driven by reverse causality.

\section{Conclusions}

We develop a portfolio model of interest differentials based on Bernoth, von Hagen, and Schuknecht (2004). In this model, interest rate differentials increase with a relative worsening of the fiscal position. The model is augmented to account for fiscal creative accounting and fiscal transparency. Creative accounting appearing in the media constitutes a news signal. The more reliable this signal, the greater will be the effect of creative accounting on the expected fiscal position of a country. Creative accounting news should therefore increase the default risk premium. Fiscal

\footnotetext{
${ }^{23}$ Thanks to Mark Hallerberg for providing us with the data on raw ideological distance. Raw ideological distance is measured according to the Manifesto Project, which codes the distance among parties based on their election manifestos in multiple dimensions.
} 
transparency should reduce spreads through lowering of uncertainty of fiscal policy. In addition, it influences the relative information content of the official and the news signal as more transparent countries probably provide more reliable official data.

The empirical results confirm the hypotheses derived from the model. Creative accounting increases risk premia. The gimmickry events, that make it in the financial news, have strong punishing effects on risk premia. This is especially true, if a country is in-transparent, as financial markets then take gimmickry as a "tip of the iceberg" signal. Creative accounting thus increases the cost of borrowing significantly, if it becomes known, especially if financial markets are unsure about the true extent of creative accounting. Deficits and creative accounting are penalized less in EMU. This suggests that central banks should increase their effort to monitor fiscal policy and to publicly stress the importance of sound fiscal policies. Fiscal transparency is connected with lower risk premia in our estimations. Instrumental variable regressions confirm the results by addressing potential simultaneity and attenuation biases.

The results highlight the importance of fiscal transparency for the credibility of governments. More transparent governments benefit from a significantly lower risk premium. Moreover, our results show that financial markets penalize fiscal misreporting heavily, which suggests that they are not fooled. In the monetary union, financial markets care less about hidden as well as official fiscal policy, however.

\section{References}

Alesina, A., M. De Broeck, A. Prati, and G. Tabellini (1992): "Default Risk on Government Debt in OECD Countries," Economic Policy, 15, 427-451.

Alt, J. E., And D. D. LAssen (2006): "Transparency, Political Polarization, and Political Budget Cycles in OECD Countries," American Journal of Political Science, 50(3).

Baele, L., A. Ferrando, P. Hördahl, E. Krylova, and C. Monnet (2004): "Measuring European Financial Integration," Oxford Review of Economic Policy, 20(4), 509-530.

Bernoth, K., J. von Hagen, and L. Schuknecht (2004): "Sovereign Risk Premia in the European Government Bond Market," ECB Working paper, 369. 
Bohn, H., and R. P. Inman (1996): "Balanced Budget Rules and Public Deficits: Evidence from the U.S. States," NBER Working Paper, 5533.

Bunch, B. S. (1991): "The Effect of Constitutional Debt Limits on State Governments' Use of Public Authorities," Public Choice, 68, 57-69.

Buti, M., J. N. Martins, and A. Turrini (2006): "From Deficits to Debt and Back: Political Incentives under Numerical Fiscal Rules," European Commission mimeo.

Capeci, J. (1991): "Credit Risk, Credit Ratings, and Municipal Bond Yields: A Panel Study," National Tax Journal, 44 (1), 41-56.

- (1994): "Local Fiscal Policies, Default Risk, and Municipal Borrowing Costs," Journal of Public Economics, 53, 73-89.

Codogno, L., C. Favero, and A. Missale (2003): "Yield Spreads on EMU Government Bonds," Economic Policy, pp. 503-32.

Dafflon, B., And S. Rossi (1999): "Public Accounting Fudges Towards EMU: A First Empirical Survey and some Public Choice Considerations," Public Choice, 101, 59-84.

Dungey, M., V. Martin, And A. P. Pagan (2000): "A Multivariate Latent Factor Decomposition of International Bond Yield Spreads," Journal of Applied Econometrics, 15, 697-715.

European Comission, DG for Economic and Financial Affairs (2003): Public Finances in EMU 2003. The European Commission, Brussels.

Favero, C., and F. Giavazzi (2004): "Inflation Targeting and Debt: Lessons from Brazil?," NBER Working Paper, No. 10390.

Favero, C., F. Giavazzi, and L. Spaventa (1997): "High Yields: The Spread on German Interest Rates," The Economic Journal, 107, 956-85.

Flemming, M. J. (2003): "Measuring Treasury Market Liquidity," Federal Reserve Bank of New York Economic Policy review, 9, 83-108.

Gelos, R. G., And S.-J. Wei (2005): "Transparency and International Portfolio Holdings," The Journal of Finance, 60 (6), 2987-3020. 
Glennerster, R., And Y. Shin (2006): "Do Sovereign Bond Markets Reward Transparency?," mimeo.

Gómez-Puig, M. (2006): "Size Matters for Liquidity: Evidence from EMU Sovereign Yield Spreads," Economics Letters, 90, 156-162.

Gravelle, T. (1999): "Liquidity of the Governemtn of Canada Securities Market: Stylized Facts and some Market Microstructure Comparisons to the United States Treasurey Market," Bank of Canada Working Paper, 99-11.

Hallerberg, M. (2004): Domestic Budgets in a United Europe: Fiscal Governance from the End of Bretton Woods to EMU. Cornell University Press.

Hallerberg, M., R. Strauch, and J. von Hagen (2001): "The Use and Effectiveness of Budgetary Rules and Norms in EU Member States," Discussion Paper Report, Dutch Ministry of Finance.

(2005): "Fiscal Rules in the European Union 1991-2001: Updating the Von Hagen Fiscal Index," mimeo.

Kiewiet, D., And K. Szakaly (1996): "Constitutional Limitations on Borrowing: Analysis of State Bonded Indebtedness," Journal of Economics, Law, and Organization, April, 62-97.

Koen, V., And P. van den Noord (2005): "Fiscal Gimmickry in Europe: OneOff Meausres and Creative Accounting," OECD Economics Department Working Paper, 2005(4).

Kopits, G., And J. Craig (1998): "Transparency in Government Operations," IMF occassional paper, No 158.

Milesi-Ferretti, G. (2003): "Good, Bad or Ugly? On the Effects of Fiscal Rules with Creative Accounting," Journal of Public Economics, 88, 377-394.

Milesi-Ferretti, G., and K. Moriyama (2004): "Fiscal Adjustment in EU Countries: A Balance Sheet Approach," IMF Working Paper, 04/143.

Pagano, M., and E.-L. V. Thadden (2004): "The European Bond Markets under EMU," Oxford Review of Economic Policy, 20 (4), 531-554.

Poterba, J., And J. von Hagen (1999): Fiscal Institutions and Fiscal Performance. University of Chicago Press, Chicago. 
von Hagen, J. (1991): "A Note on the Empirical Effectiveness of Formal Fiscal Restraints," Journal of Public Economics, 44, 199 - 210.

(1992): "Budgeting Procedures and Fiscal Performance in the European Communities," Economic Papers, 96.

von Hagen, J., and G. B. Wolff (2006): "What Do Deficits Tell Us About Debt? Empirical Evidence on Creative Accounting with Fiscal Rules in the EU," Journal of Banking and Finance (CEPR DP 4759), forthcoming. 


\section{Graphs}

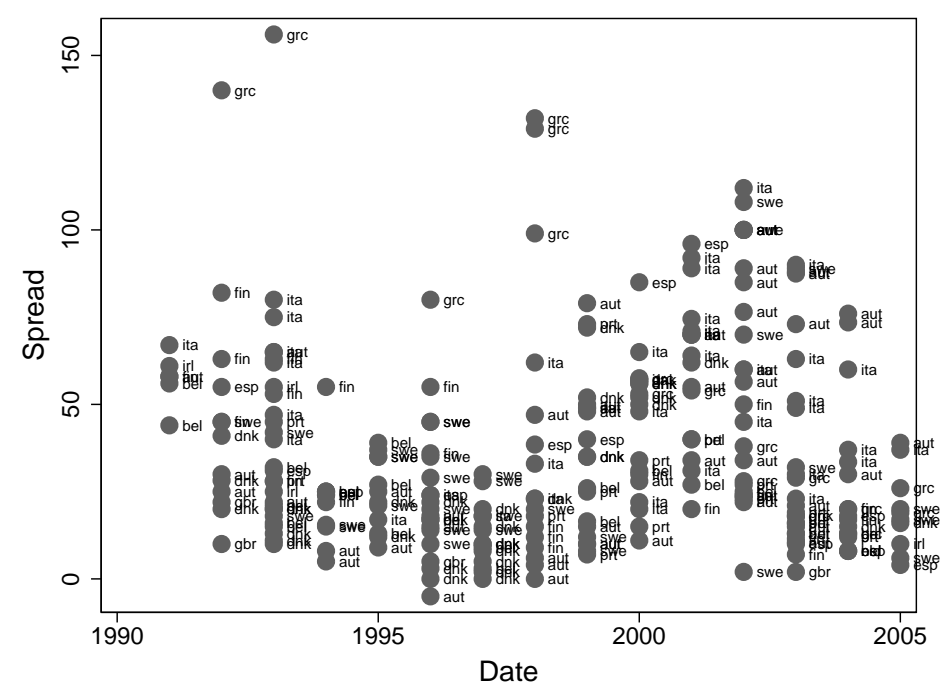

Figure 2: Interest rate spreads for central government primary debt issues vs benchmark countries Germany or USA in basis points.

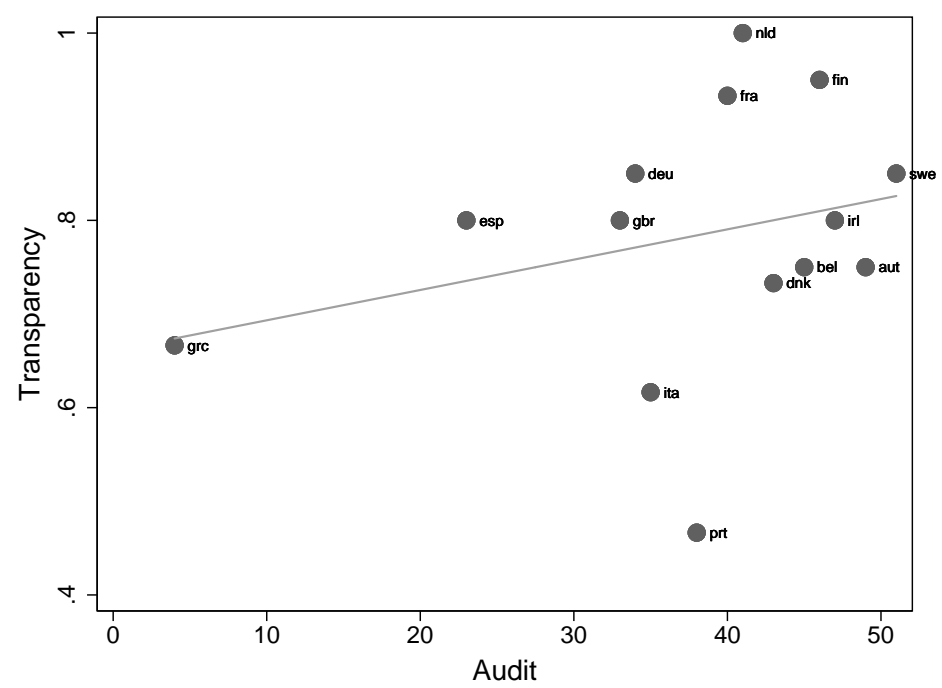

Figure 3: A comparison of two indices of fiscal transparency. 


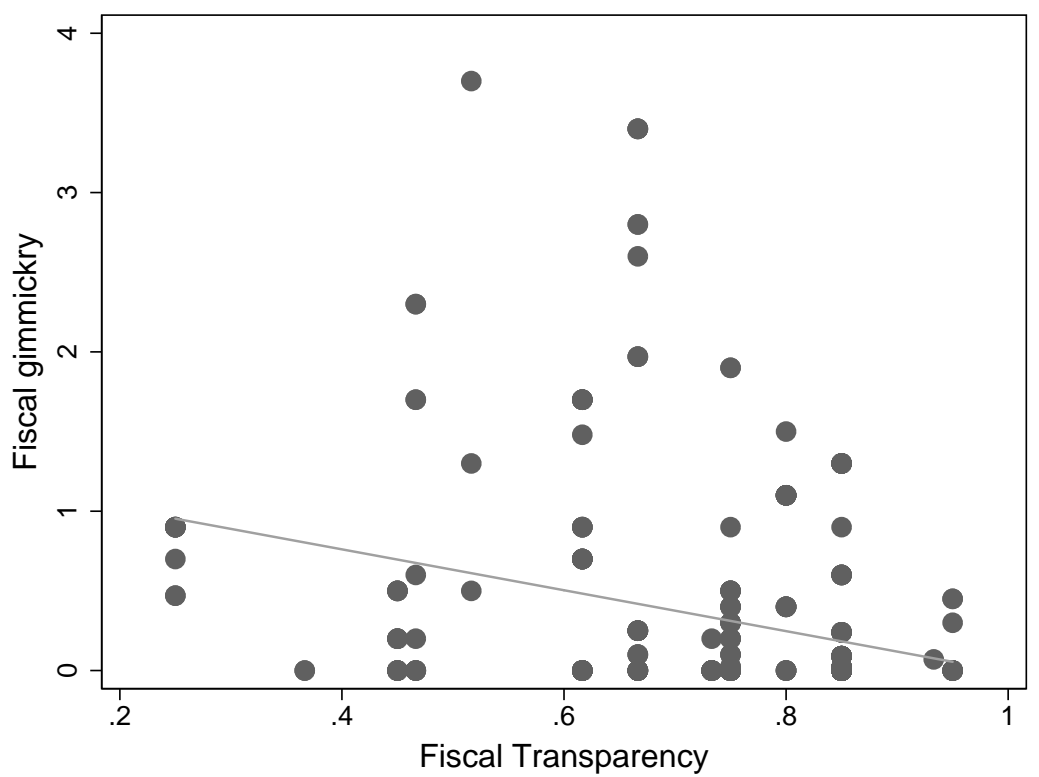

Figure 4: Fiscal gimmickry as a function of transparency.

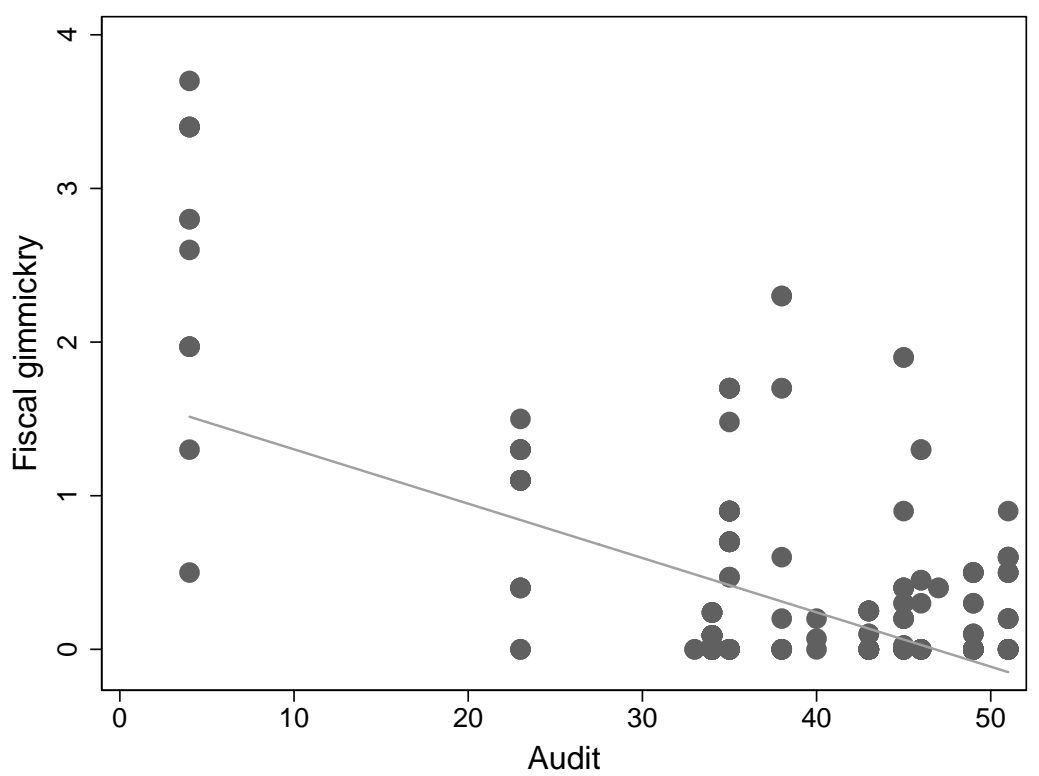

Figure 5: Fiscal gimmickry as a function of Audit. 


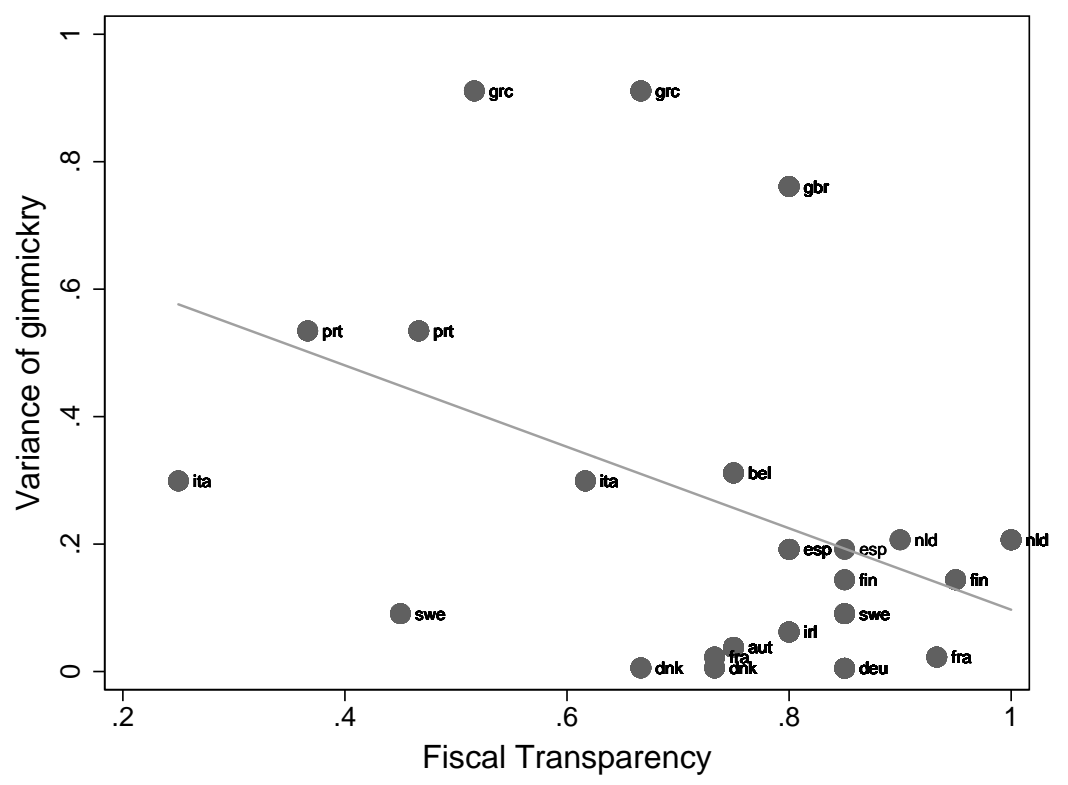

Figure 6: The variance of gimmickry as a function of transparency.

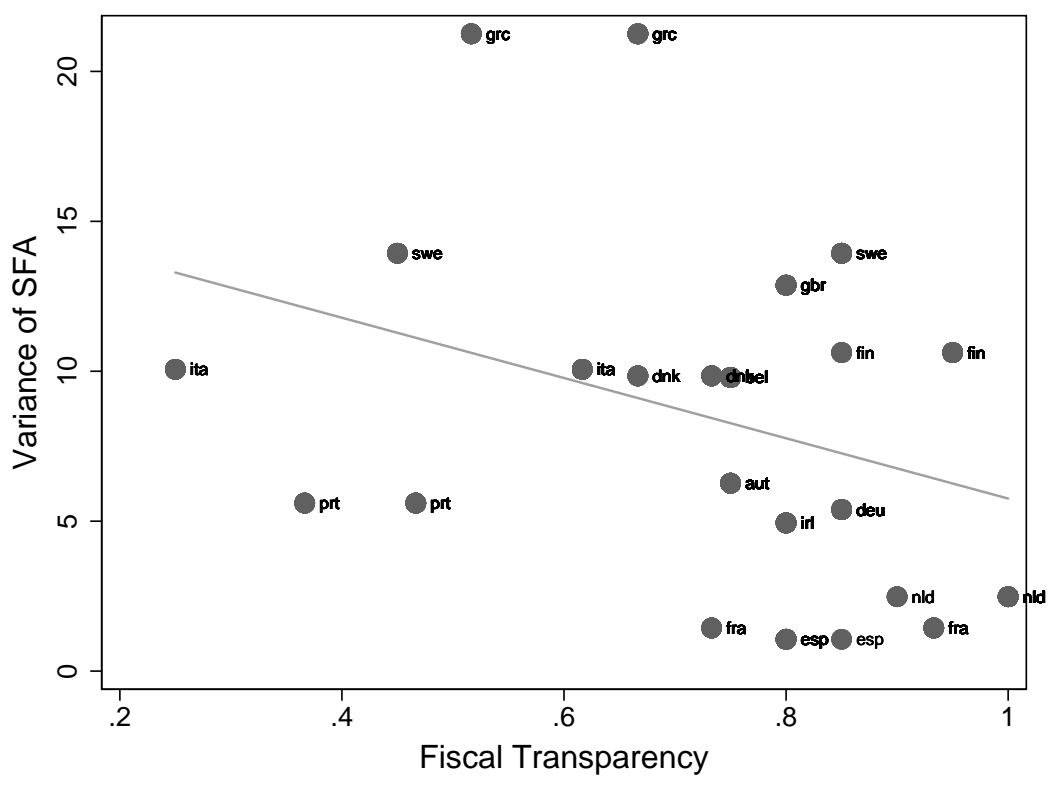

Figure 7: The variance of stock-flow adjustments as a function of transparency. 


\begin{tabular}{|c|c|c|c|c|c|}
\hline Variable & Desciption & Average & Std. Dev. & Min. & Max. \\
\hline Spread $\mathrm{S}_{i t}$ & $\begin{array}{l}\text { The spread between the yield of a government bond issue of an EU country and a } \\
\text { comparable goverment bond issued in the same currency related to the gross nominal } \\
\text { retum of the government bond issue. Expressed in basis points. Compare equation } \\
\text { (11). Source: Capital DATA Bondware }\end{array}$ & 37.29 & 28.56 & -5.00 & 156.00 \\
\hline $\begin{array}{l}\text { Stock-Flow- } \\
\text { Adjustment }\end{array}$ & $\begin{array}{l}\text { Difference of stock-flow adjustment to GDP at the end of the fiscal year between the } \\
\text { issuer country and the benchmark country (expressed in percent). Source: European } \\
\text { Commission (Ameco database) }\end{array}$ & 0.51 & 6.44 & -14.67 & 14.24 \\
\hline Debt (lagged) & $\begin{array}{l}\text { Difference of lagged debt to GDP outstanding at the end of the fiscal year between the } \\
\text { issuer country and the benchmark country (expressed in percent). Source: European } \\
\text { Commission (Ameco database) }\end{array}$ & 13.86 & 26.63 & -44.05 & 87.88 \\
\hline Audit & $\begin{array}{l}\text { Measures the degree to which fiscal book keeping is being audited and the extent to } \\
\text { which which this information is disseminated. Difference of audit relative to benchmark } \\
\text { country, described in more detail in section } 7 \text { of the paper. }\end{array}$ & 0.04 & 0.19 & -0.56 & 0.27 \\
\hline & $\begin{array}{l}\text { Measures the informativeness of the budget draft. It includes an assessment of } \\
\text { transparency given by government officials, the degree to which special funds are }\end{array}$ & & & & \\
\hline Transparency & $\begin{array}{l}\text { induded in the budget draft, the information whether the budget consists of one } \\
\text { document, whether it is linked to national accounts and finally whether govemment } \\
\text { loans are included. Taken from Hallerberg, Strauch, von Hagen (2005). }\end{array}$ & 0.69 & 0.16 & 0.25 & 1.00 \\
\hline Liquidity & $\begin{array}{l}\text { The ratio of the total debt of the issuer country over the total debt of the EU issued in } \\
\text { DM/Euro or US } \$ \text {. Source: DBSonline, BIS and own calculations. }\end{array}$ & 13.64 & 12.89 & 0.11 & 53.82 \\
\hline Business Cycle & $\begin{array}{l}\text { The difference of the business cycle variable between the issuer country and the } \\
\text { benchmark county, which collates the value } 1 \text { when the detrended and standardized } \\
\text { nominal GDP is bigger than } 0.5 \text {, the value }-1 \text {, when it is smaller then }-0.5 \text { and } 0 \\
\text { otherwise. }\end{array}$ & -0.05 & 1.05 & -2.00 & 2.00 \\
\hline
\end{tabular}

Table 3: Descriptive statistics and sources of the variables. 


\section{A new index of fiscal transparency}

Fiscal transparency is an important concept, which is difficult to measure. In this paper, we focus on the narrow concept of "information" transparency. Our index "Audit" captures the degree to which fiscal book keeping is being audited and the extent to which the information of this auditing becomes public knowledge. A further aspect of Audit relates to potential political pressure that results from the auditing results.

Audit is based on a OECD/World Bank survey of budget practice, which was launched in February 2003, in more than 60 countries. $^{24}$ In the survey, question are asked regarding (1) general information on government budget organization, (2) budget formulation, (3) budget execution, (4) accounting, control and monitoring systems, (5) budget documentation and performance management, (6) fiscal relations among levels of government, and (7) special relationships and issues.

We took the responses on question in the area (4), more specifically 4.5a-4.5t. The questions and our coding are listed below. To each question, we assigned a value between zero and four, where four indicates the response most conducive to fiscal "transparency". The index is computed as the simple sum of the responses to all individual questions. We also computed the average response for every country. This alternative index, however, appears to capture the true extent of auditing less adequately, as non-response is not counted. Especially Greece leaves a significant amount of questions unanswered. We believe, that it is reasonable to assume that partial non-response is a sign of very bad auditing quality.

${ }^{24}$ The results are available at http://ocde.dyndns.org/ 
Table 4: The external audit index

\begin{tabular}{lc}
\hline \hline Country & External audit, index value \\
AUSTRIA & 49 \\
BELGIUM & 45 \\
DENMARK & 43 \\
FINLAND & 46 \\
FRANCE & 40 \\
GERMANY & 34 \\
GREECE & 4 \\
IRELAND & 47 \\
ITALY & 35 \\
NETHERLANDS & 41 \\
NORWAY & 41 \\
PORTUGAL & 38 \\
SPAIN & 23 \\
SWEDEN & 51 \\
UNITED KINGDOM & 33 \\
UNITED STATES & 40 \\
\hline Notes: Authors' calculation based on World Bank/OECD survey.
\end{tabular}

\section{Question:}

Are government entities subject to financial audits by an external auditor?

Is there a central Supreme or National Audit Office

\section{Coding of the answers devel- oped by the authors.}

yes $=4$, no $=0$
Yes, reports to legislative branch $=4$, Yes, reports to the executive branch $=2$, Yes, reports to judiciary branch $=1$; Other, please specify $=0$

Yes to private firms $=4$; Yes to other independent government bodies $=2.5$; Yes, other please specify $=1, \mathrm{No}=0$

Yes, it is a routine practice $=4$, Yes, on an ad hoc basis $=2, \mathrm{No}=0$

reviewed by other countrys audit offices? 
How would external audit arrangements be described?

How is the independence of the National Audit Body from the executive established?

What mandate does the National Audit Body have?

Are the findings of the National Audit Body available to the public?

Does the external auditor conduct performance audits?

Is there a materiality level or other risk management procedure that limits the number of governmental organisations or entities subject to audit?
There is no formal external audit of government accounts $=0$; The audit authority reports only within the executive (e.g., to the President $=1$; A National Audit Body, independent of the executive, audits government accounts and reports to the executive $=2$; The National Audit Body is a legislative body $=3$; A National Audit Body, independent of the executive, audits government accounts and reports to the legislature $=4$

It is established in the constitution $=4$; It is established in law $=3$; It is set out in administrative regulation $=1$; It is not clearly set out in law $=0$

0 to 4 (most functions)

Always $=4 ;$ Generally, but with some exceptions (e.g., audits of the military $)=2$; Never or rarely $=0$

$\mathrm{Yes}=4, \mathrm{No}=0$

yes $=0$, no $=4$ 
Are audit results circulated and discussed in Parliament?

How are the subjects of audits determined?

Is there a system to track audit recommendations once issued?

Is the executive branch required by constitution or legislation to follow up and respond to national audit body recommendations?

Does the Supreme Audit body coordinate with or use the reports of internal auditors?

Does the legislature have an audit body that is not affiliated with the National Audit Body? no $=0$, No, the reports are too late $=1$; Yes, by Budget committee $=2$; Yes, by oversight committee $(\mathrm{s})=3$; Yes, by General Assem$\mathrm{bly}=4$

By legislative branch request $=4$; By request from the public or other civil society actor $=3$; Internally determined $=2$; By executive branch request $=1$; Other, please specify $=0$

Yes, keeps track of implementation of recommendations $=4$; Yes, an annual report is issued of recommendations $=3$; Yes, but the reports are kept internally $=1 ; \mathrm{No}=0$

yes $=4$; Yes, but there is a procedure by which the executive may reject the recommendation $=3 ; \mathrm{No}$, but it generally does $=1 ; \mathrm{No}=0$

all yes $=4 . \mathrm{No}=0$

yes $=4$, no $=0$ 


\title{
CESifo Working Paper Series
}

\author{
(for full list see www.cesifo-group.de)
}

1669 Françoise Forges and Frédéric Koessler, Long Persuasion Games, February 2006

1670 Florian Englmaier and Markus Reisinger, Information, Coordination, and the Industrialization of Countries, February 2006

1671 Hendrik Hakenes and Andreas Irmen, Something out of Nothing? Neoclassical Growth and the 'Trivial' Steady State, February 2006

1672 Torsten Persson and Guido Tabellini, Democracy and Development: The Devil in the Details, February 2006

1673 Michael Rauber and Heinrich W. Ursprung, Evaluation of Researchers: A Life Cycle Analysis of German Academic Economists, February 2006

1674 Ernesto Reuben and Frans van Winden, Reciprocity and Emotions when Reciprocators Know each other, February 2006

1675 Assar Lindbeck and Mats Persson, A Model of Income Insurance and Social Norms, February 2006

1676 Horst Raff, Michael Ryan and Frank Staehler, Asset Ownership and Foreign-Market Entry, February 2006

1677 Miguel Portela, Rob Alessie and Coen Teulings, Measurement Error in Education and Growth Regressions, February 2006

1678 Andreas Haufler, Alexander Klemm and Guttorm Schjelderup, Globalisation and the Mix of Wage and Profit Taxes, February 2006

1679 Kurt R. Brekke and Lars Sørgard, Public versus Private Health Care in a National Health Service, March 2006

1680 Dominik Grafenhofer, Christian Jaag, Christian Keuschnigg and Mirela Keuschnigg, Probabilistic Aging, March 2006

1681 Wladimir Raymond, Pierre Mohnen, Franz Palm and Sybrand Schim van der Loeff, Persistence of Innovation in Dutch Manufacturing: Is it Spurious?, March 2006

1682 Andrea Colciago, V. Anton Muscatelli, Tiziano Ropele and Patrizio Tirelli, The Role of Fiscal Policy in a Monetary Union: Are National Automatic Stabilizers Effective?, March 2006

1683 Mario Jametti and Thomas von Ungern-Sternberg, Risk Selection in Natural Disaster Insurance - the Case of France, March 2006 
1684 Ken Sennewald and Klaus Waelde, “Itô's Lemma“ and the Bellman Equation for Poisson Processes: An Applied View, March 2006

1685 Ernesto Reuben and Frans van Winden, Negative Reciprocity and the Interaction of Emotions and Fairness Norms, March 2006

1686 Françoise Forges, The Ex Ante Incentive Compatible Core in Exchange Economies with and without Indivisibilities, March 2006

1687 Assar Lindbeck, Mårten Palme and Mats Persson, Job Security and Work Absence: Evidence from a Natural Experiment, March 2006

1688 Sebastian Buhai and Coen Teulings, Tenure Profiles and Efficient Separation in a Stochastic Productivity Model, March 2006

1689 Gebhard Kirchgaessner and Silika Prohl, Sustainability of Swiss Fiscal Policy, March 2006

1690 A. Lans Bovenberg and Peter Birch Sørensen, Optimal Taxation and Social Insurance in a Lifetime Perspective, March 2006

1691 Moritz Schularick and Thomas M. Steger, Does Financial Integration Spur Economic Growth? New Evidence from the First Era of Financial Globalization, March 2006

1692 Burkhard Heer and Alfred Maussner, Business Cycle Dynamics of a New Keynesian Overlapping Generations Model with Progressive Income Taxation, March 2006

1693 Jarko Fidrmuc and Iikka Korhonen, Meta-Analysis of the Business Cycle Correlation between the Euro Area and the CEECs, March 2006

1694 Steffen Henzel and Timo Wollmershaeuser, The New Keynesian Phillips Curve and the Role of Expectations: Evidence from the Ifo World Economic Survey, March 2006

1695 Yin-Wong Cheung, An Empirical Model of Daily Highs and Lows, March 2006

1696 Scott Alan Carson, African-American and White Living Standards in the $19^{\text {th }}$ Century American South: A Biological Comparison, March 2006

1697 Helge Berger, Optimal Central Bank Design: Benchmarks for the ECB, March 2006

1698 Vjollca Sadiraj, Jan Tuinstra and Frans van Winden, On the Size of the Winning Set in the Presence of Interest Groups, April 2006

1699 Martin Gassebner, Michael Lamla and Jan-Egbert Sturm, Economic, Demographic and Political Determinants of Pollution Reassessed: A Sensitivity Analysis, April 2006

1700 Louis N. Christofides and Amy Chen Peng, Major Provisions of Labour Contracts and their Theoretical Coherence, April 2006 
1701 Christian Groth, Karl-Josef Koch and Thomas M. Steger, Rethinking the Concept of Long-Run Economic Growth, April 2006

1702 Dirk Schindler and Guttorm Schjelderup, Company Tax Reform in Europe and its Effect on Collusive Behavior, April 2006

1703 Françoise Forges and Enrico Minelli, Afriat's Theorem for General Budget Sets, April 2006

1704 M. Hashem Pesaran, Ron P. Smith, Takashi Yamagata and Liudmyla Hvozdyk, Pairwise Tests of Purchasing Power Parity Using Aggregate and Disaggregate Price Measures, April 2006

1705 Piero Gottardi and Felix Kubler, Social Security and Risk Sharing, April 2006

1706 Giacomo Corneo and Christina M. Fong, What's the Monetary Value of Distributive Justice?, April 2006

1707 Andreas Knabe, Ronnie Schoeb and Joachim Weimann, Marginal Employment Subsidization: A New Concept and a Reappraisal, April 2006

1708 Hans-Werner Sinn, The Pathological Export Boom and the Bazaar Effect - How to Solve the German Puzzle, April 2006

1709 Helge Berger and Stephan Danninger, The Employment Effects of Labor and Product Markets Deregulation and their Implications for Structural Reform, May 2006

1710 Michael Ehrmann and Marcel Fratzscher, Global Financial Transmission of Monetary Policy Shocks, May 2006

1711 Carsten Eckel and Hartmut Egger, Wage Bargaining and Multinational Firms in General Equilibrium, May 2006

1712 Mathias Hoffmann, Proprietary Income, Entrepreneurial Risk, and the Predictability of U.S. Stock Returns, May 2006

1713 Marc-Andreas Muendler and Sascha O. Becker, Margins of Multinational Labor Substitution, May 2006

1714 Surajeet Chakravarty and W. Bentley MacLeod, Construction Contracts (or "How to Get the Right Building at the Right Price?”), May 2006

1715 David Encaoua and Yassine Lefouili, Choosing Intellectual Protection: Imitation, Patent Strength and Licensing, May 2006

1716 Chris van Klaveren, Bernard van Praag and Henriette Maassen van den Brink, Empirical Estimation Results of a Collective Household Time Allocation Model, May 2006 
1717 Paul De Grauwe and Agnieszka Markiewicz, Learning to Forecast the Exchange Rate: Two Competing Approaches, May 2006

1718 Sijbren Cnossen, Tobacco Taxation in the European Union, May 2006

1719 Marcel Gérard and Fernando Ruiz, Interjurisdictional Competition for Higher Education and Firms, May 2006

1720 Ronald McKinnon and Gunther Schnabl, China's Exchange Rate and International Adjustment in Wages, Prices, and Interest Rates: Japan Déjà Vu?, May 2006

1721 Paolo M. Panteghini, The Capital Structure of Multinational Companies under Tax Competition, May 2006

1722 Johannes Becker, Clemens Fuest and Thomas Hemmelgarn, Corporate Tax Reform and Foreign Direct Investment in Germany - Evidence from Firm-Level Data, May 2006

1723 Christian Kleiber, Martin Sexauer and Klaus Waelde, Bequests, Taxation and the Distribution of Wealth in a General Equilibrium Model, May 2006

1724 Axel Dreher and Jan-Egbert Sturm, Do IMF and World Bank Influence Voting in the UN General Assembly?, May 2006

1725 Swapan K. Bhattacharya and Biswa N. Bhattacharyay, Prospects of Regional Cooperation in Trade, Investment and Finance in Asia: An Empirical Analysis on BIMSTEC Countries and Japan, May 2006

1726 Philippe Choné and Laurent Linnemer, Assessing Horizontal Mergers under Uncertain Efficiency Gains, May 2006

1727 Daniel Houser and Thomas Stratmann, Selling Favors in the Lab: Experiments on Campaign Finance Reform, May 2006

1728 E. Maarten Bosker, Steven Brakman, Harry Garretsen and Marc Schramm, A Century of Shocks: The Evolution of the German City Size Distribution 1925 - 1999, May 2006

1729 Clive Bell and Hans Gersbach, Growth and Enduring Epidemic Diseases, May 2006

1730 W. Bentley MacLeod, Reputations, Relationships and the Enforcement of Incomplete Contracts, May 2006

1731 Jan K. Brueckner and Ricardo Flores-Fillol, Airline Schedule Competition: ProductQuality Choice in a Duopoly Model, May 2006

1732 Kerstin Bernoth and Guntram B. Wolff, Fool the Markets? Creative Accounting, Fiscal Transparency and Sovereign Risk Premia, May 2006 